\title{
Energetics of Acetylcholinesterase Inhibition by Alkylphenyl Methylcarbamates
}

\author{
Yehia A. I. AbDEL-AaL \\ Plant Protection Department, College of Agriculture, \\ Assiut University, Assiut, A. R. Egypt
}

(Received May 11, 1982)

Phenyl $N$-methylcarbamates (CX) react with acetylcholinesterase (E) by a three step mechanism shown in Eq. (1) where $k_{1}, k_{-1}, k_{2}$ and $k_{3}$ are the rate constants of elementary steps and $k_{-1} \gg k_{2} \gg k_{3}{ }^{1-4)}$

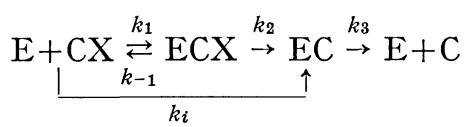

Thus the anticholinesterase activity of the carbamates $\left(k_{i}\right)$ is mainly controlled by the equilibrium dissociation constant $K_{\mathrm{d}}\left(=k_{-1} / k_{1}\right)$ and the carbamylation rate constant $k_{2}$. These inhibition kinetic parameters are related: $k_{i}=k_{2} / K_{\mathrm{d}} \cdot{ }^{5-7)}$ The structure activity correlations of carbamate cholinesterase inhibitors have been reviewed by Metcalf. ${ }^{4)}$

Recently, the inhibitory activity of substituted phenyl $N$-methylcarbamates to honey bee acetylcholinesterase has been analysed by means of regression analysis and free-energy related physicochemical substituent constants such as $\sigma$ and $\pi .^{8,9)}$ The purpose of the present investigation is to ascertain how and to what extent the thermodynamic quantities associated with honey bee acetylcholinesterase inhibition vary with structural change of alkylphenyl $N$-methylcarbamates.

\section{MATERIALS AND METHODS}

\section{Inhibitors}

Meta- and para-alkylphenyl $N$-methylcarbamates were prepared from commercially available appropriate phenols and methylisocyanate using triethylamine as a catalyst according to Kolbezen et al. ${ }^{10)}$ Stock solutions (0.1 M) were prepared in acetone and stored at $-20^{\circ} \mathrm{C}$. Further dilutions from these stock solutions were made in acetone immediately before use.

\section{Enzyme Preparation}

Adult bee workers were frozen at $-20^{\circ} \mathrm{C}$ and heads were ground in a cold solution of $0.1 \mathrm{M}$ sodium phosphate buffer, $\mathrm{pH} 7.0$ (25 heads $/ \mathrm{ml})$. The slurry was centrifuged at $6,400 \mathrm{rpm}$ for $15 \mathrm{~min}$ and the supernatant was withdrawn from beneath this with a syringe.

\section{Enzyme Activity}

The enzyme assays were performed at the desired temperature by the colorimetric method of Ellman et al. ${ }^{11)}$ A mixture was prepared consisting of $4.5 \mathrm{ml}$ of buffer $(0.1 \mathrm{M}$ sodium phosphate, $\mathrm{pH} 7.6), 0.1 \mathrm{ml}$ of $0.01 \mathrm{~m}$ solution of DTNB[5,5-dithiobis-(2-nitrobenzoic acid)] plus $0.018 \mathrm{M}$ sodium bicarbonate in $0.1 \mathrm{M}$ sodium phosphate buffer ( $\mathrm{pH} 7.0)$. This mixture was placed into the cuvette and $0.05 \mathrm{ml}$ of the enzyme preparation was added followed by $0.1 \mathrm{ml}$ acetone or acetone-inhibotor solutions. At suitable time intervals $(0.25-4 \mathrm{~min})$, $0.1 \mathrm{ml}$. of a $0.1 \mathrm{~m}$ of acetylthiocholine iodide (in freshly distilled water) was added. After rapid mixing, the extinction at $412 \mathrm{~nm}$ was recorded at $30 \mathrm{sec}$ intervals for $4 \mathrm{~min}$, the first reading being taken $15 \mathrm{sec}$ after the substrate had been added. Activity was estimated from the initial slope of the plot of absorbance against time. At least five concentrations from each inhibitor were used and the results reported are the means of at least three determinations. 


\section{Inhibition Constants}

Detailed kinetic treatment ${ }^{7)}$ were developed for bee head acetylcholinesterase to allow the separation of $k_{i}$, the overall bimolecular inhibition reaction constant into a carbamylation rate constant $\left(k_{2}\right)$ and an affinity constant, $K_{\mathrm{a}}\left(1 / K_{\mathrm{d}}\right)$. Pseudo first order plots of log per cent residual activity $(\log V)$ against preincubation time $(t)$ were plotted. The slope of these plots $(\Delta \log V / \Delta t)$ was transformed into the form (i) $\Delta t / 2.303 \Delta \log V$ and the latter was plotted vs. the inhibitor concentration $(i)$. The plots fit a straight line rather well according to the equation (i) $\Delta t / 2.303 \Delta \log V=(i) / k_{2}+$ $1 / k_{1}{ }^{7)}$ The slope will be $1 / k_{2}$, the intercept on the $(i)$ axis will be $-K_{\mathrm{d}}$, and the intercept on the (i) $\Delta t / 2.303 \Delta \log V$ axis will be $1 / k_{i}$.

\section{RESULTS AND DISCUSSION}

The effect of meta and para alkyl substitution of phenyl methylcarbamate on honey bee acetylcholinesterase inhibition was examined at two different temperatures (Table 1) enabling some thermodynamic quantities to be evaluated (Table 2). For relating the anticholinesterase activity with structural change, the bimolecular inhibition reaction constant $\left(k_{i}\right)$ of the tested compounds at the same temperature (298K) was compared. As seen in Table 1, substitution with methyl, ethyl, isopropyl and tert-butyl in the meta position of phenyl methylcarbamate increases the anticholinesterase activity 7.13-, 75.4-, 772.4- and 483.7 times, respectively. This indicates that the activity increases as the substituent increases in size to three carbon atoms. The increased inhibitory activity of meta alkylphenyl methylcarbamates was also demonstrated against the enzyme acetylcholinesterase from other insect species. ${ }^{4,8}$ Theoretically this increase in reaction constant may be due to a decrease in the activation energy $\left(E_{\mathrm{a}}\right)$, an increase in the $P Z$ factor, or their combined effect according to the collision theory of reaction rates which denotes:

$$
k_{i}=P Z \exp \left(-E_{\mathrm{a}} / R T\right)
$$

where $Z$ is the number of collisions occurring between carbamate and acetylcholinesterase $(\mathrm{AChE})$ in unit volume per unit time, $\exp \left(-E_{\mathrm{a}} /\right.$ $R T)$ is the frequency factor which measures the probability that any molecule will have sufficient energy to react, and $P$ is the steric factor giving the fraction of energetically

Table 1 Inhibition kinetic parameters of honey bee acetylcholinesterase by $m$ - and $p$ alkylphenyl methylcarbamates.

General formula: $X_{6} \mathrm{C}_{4} \mathrm{OC}(\mathrm{O}) \mathrm{NHCH}_{3}$

\begin{tabular}{lcccc}
\hline$X$ & Temp. $(\mathrm{K})$ & $\begin{array}{c}k_{i} \\
\left(l / \mathrm{mol}, \mathrm{sec} \times 10^{2}\right)\end{array}$ & $\begin{array}{c}K_{\mathrm{a}} \\
\left(\mathrm{M}^{-1}\right)\end{array}$ & $\begin{array}{c}k_{2} \\
\left(\mathrm{sec}^{-1} \times 10^{-2}\right)\end{array}$ \\
\hline $\mathrm{H}$ & 298 & $1.23 \pm 0.05$ & $6.25 \times 10^{3}$ & $1.97 \pm 0.09$ \\
& 308 & $1.41 \pm 0.03$ & $1.49 \times 10^{3}$ & $9.46 \pm 0.40$ \\
$3-\mathrm{CH}_{3}$ & 298 & $8.77 \pm 0.16$ & $1.25 \times 10^{4}$ & $7.02 \pm 0.47$ \\
& 303 & $10.10 \pm 0.29$ & $1.79 \times 10^{4}$ & $5.64 \pm 0.27$ \\
$3-\mathrm{C}_{2} \mathrm{H}_{5}$ & 298 & $92.70 \pm 3.89$ & $2.08 \times 10^{5}$ & $4.46 \pm 0.34$ \\
& 308 & $150.00 \pm 6.11$ & $3.29 \times 10^{5}$ & $4.56 \pm 0.20$ \\
$3-\mathrm{CH}\left(\mathrm{CH}_{3}\right)_{2}$ & 291 & $575.00 \pm 29.09$ & $1.25 \times 10^{6}$ & $4.60 \pm 0.29$ \\
& 298 & $950.00 \pm 84.45$ & $1.92 \times 10^{6}$ & $4.95 \pm 0.29$ \\
$3-\mathrm{C}\left(\mathrm{CH}_{3}\right)_{3}$ & 298 & $595.00 \pm 14.93$ & $1.25 \times 10^{6}$ & $4.76 \pm 0.30$ \\
& 303 & $980.00 \pm 63.00$ & $1.43 \times 10^{6}$ & $6.85 \pm 0.28$ \\
$4-\mathrm{CH}_{3}$ & 298 & $0.92 \pm 0.01$ & $8.55 \times 10^{2}$ & $11.00 \pm 0.50$ \\
& 303 & $1.19 \pm 0.03$ & $3.52 \times 10^{2}$ & $34.00 \pm 3.06$ \\
$4-\mathrm{C}_{2} \mathrm{H}_{5}$ & 298 & $0.65 \pm 0.02$ & $3.58 \times 10^{2}$ & $18.00 \pm 2.65$ \\
& 303 & $0.97 \pm 0.12$ & $8.33 \times 10^{2}$ & $12.00 \pm 1.15$ \\
$4-\mathrm{C}\left(\mathrm{CH}_{3}\right)_{3}$ & 298 & $0.22 \pm 0.006$ & $5.75 \times 10^{2}$ & $3.83 \pm 0.24$ \\
& 311 & $1.13 \pm 0.04$ & $1.37 \times 10^{3}$ & $8.25 \pm 0.96$
\end{tabular}


Table 2 Thermodynamic quantities of honey bee acetylcholinesterase inhibition by $m$ - and p-alkylphenyl methylcarbamates.

General formula: $X_{6} \mathrm{H}_{4} \mathrm{OC}(\mathrm{O}) \mathrm{NHCH}_{3}$

\begin{tabular}{lcccc}
\hline \multicolumn{1}{c}{$X$} & $\begin{array}{c}E_{\mathrm{a}} \\
(\mathrm{kcal} / \mathrm{mol})\end{array}$ & $\begin{array}{c}P Z \\
(l / \mathrm{mol}, \mathrm{sec})\end{array}$ & $\begin{array}{c}\Delta S^{*} \\
(\mathrm{e} . \mathrm{u} .)\end{array}$ & $\pi^{\mathrm{a})}$ \\
\hline $\mathrm{H}$ & 2.59 & $9.72 \times 10^{3}$ & -42.28 & 0.0 \\
$3-\mathrm{CH}_{3}$ & 5.06 & $4.51 \times 10^{6}$ & -30.07 & 0.51 \\
$3-\mathrm{C}_{2} \mathrm{H}_{5}$ & 8.78 & $2.55 \times 10^{10}$ & -12.92 & 0.97 \\
$3-\mathrm{CH}\left(\mathrm{CH}_{3}\right)_{2}$ & 12.36 & $1.10 \times 10^{14}$ & +3.72 & 1.30 \\
$3-\mathrm{C}\left(\mathrm{CH}_{3}\right)_{3}$ & 17.90 & $8.00 \times 10^{17}$ & +21.38 & 1.68 \\
$4-\mathrm{CH}_{3}$ & 9.42 & $7.42 \times 10^{8}$ & -19.93 & 0.52 \\
$4-\mathrm{C}_{2} \mathrm{H}_{5}$ & 14.30 & $2.00 \times 10^{12}$ & -4.23 & 0.97 \\
$4-\mathrm{C}\left(\mathrm{CH}_{3}\right)_{3}$ & 23.14 & $3.06 \times 10^{18}$ & +23.26 & 1.68 \\
\hline
\end{tabular}

a) From Hansch. ${ }^{13)}$

favourable collisions that are also sterically favourable for inhibition to take place. From $k_{i}$ values for each compound in its reaction with honey bee $\mathrm{AChE}$ at the two temperatures, $E_{\text {a }}$ was calculated according to the Arrhenius equation which denotes:

$$
\ln \frac{k_{i 2}}{k_{i 1}}=\frac{E_{\mathrm{a}}}{R}\left(\frac{1}{T_{1}}-\frac{1}{T_{2}}\right)
$$

where $R$ is the gas constant, $1.987 \mathrm{cal} / \mathrm{deg}$ mole. Listed in Table 2 are the activation energies of the tested carbamates in their reaction with honey bee AChE. Substituting for the activation energy and using $k_{i}$ values at $298 \mathrm{~K}, P Z$ factors were calculated from Eq. (2). These show, for simple alkyl substitution in the meta position, that the effect on $E_{\mathrm{a}}$ and $P Z$ factor is startling (Table 2). The increase in anticholinesterase potency is accompanied by an increase in the activation energy and the $P Z$ factor. The gradual increase in activation energy from $2.59 \mathrm{kcal} / \mathrm{mol}$ for unsubstituted phenyl methylcarbamate to $5.06,8.78,12.36$ and 17.9 , respectively, for $m$-methyl-, $m$ ethyl-, $m$-isopropyl- and $m$-tert-butylphenyl methylcarbamates indicates that the activation energy alone would have led to a reduction in the activity of the meta alkylphenyl methylcarbamates as compared with the unsubstituted parent compound. However, an increase in the $P Z$ factor as the substituent increases in size indicates conclusively that the main factor controlling the potency of the meta alkylphenyl methylcarbamates is the favourable orientation and distribution of potential energy among colliding molecules that is required for inhibition to take place. The above thermodynamic quantities in relation to meta alkyl substitution may explain the fact that these compounds are relatively ineffectual as carbamylators and their inhibitory effect is thus almost exclusively determined by their excellence as complex formers (Table 1).

In contrary, substitution with methyl, ethyl and tert-butyl in the para position slightly decrease the anticholinesterase activity, respectively, by 1.34-, 1.89- and 5.59-fold as compared with the unsubstituted phenyl methylcarbamate (Table 1). This reduction in the rate constant cannot be explained by the $P Z$ factor since the latter increases drastically over that of the parent compound. The change is particularly striking in moving from $H$ to tert-butyl. There is an increase of $2.12 \times 10^{14}$. However, greater energy barrier in the reaction of the para substituted compounds with honey bee $\mathrm{AChE}$ is absolutely responsible for their lower potency. Among all the tested analogues $p$-tert-butylphenyl methylcarbamate has the highest activation energy ( $23.14 \mathrm{kcal} /$ $\mathrm{mol})$. Comparing the meta and para substituted compounds of the same alkyl group (Table 1) indicates that meta substituted analogues are much more potent that their para isomers. In this reaction para alkylphenyl methylcarbamates are little more effective in raising the $P Z$ term but their meta analogues are still more active because of lowered activation energy. 
According to the theory of absolute reaction rates, a rate constant can be expressed in terms of the change in standard enthalpy $\Delta H^{*}$ and of the change in standard entropy $\Delta S^{*}$ of activation, Eq. (4).

$$
k_{i}=\frac{k T}{h} \exp \left(-\Delta H^{*} / R T\right) \exp \left(\Delta S^{*} / R\right)
$$

$k$ is the Boltzman constant $\left(3.298 \times 10^{-24} \mathrm{cal}\right.$. degree $\left.^{-1}\right)$ and $h$ is the Plank constant $(1.58 \times$ $\left.10^{-34} \mathrm{cal} \cdot \mathrm{sec}\right)$. From $E_{\mathrm{a}}$, the change in the standard enthalpy of activation $\left(\Delta H^{*}\right)$ is obtained from Eq. (5).

$$
\Delta H^{*}=E_{\mathrm{a}}-R T
$$

By substituting for the values of $\Delta H^{*}$ and using $k_{i}$ values at $298 \mathrm{~K}, \Delta S^{*}$ values can be obtained from Eq. (4). As would be expected, the system is more ordered or more restricted in its freedom to move, as reactants change to transition state and, therefore, $\Delta S^{*}$ will be of negative magnitude which is the case in 5 of the 8 tested compounds (Table 2). For $m$-alkylphenyl methylcarbamates, there is a decrease in the negative entropy from unsubstituted $\left(\Delta S^{*}=-42.28\right.$ e.u. $)$ to methyl $=(-30.07)$ and ethyl $(=-12.92)$ and it then becomes positive in isopropyl $(=+3.72)$ and tert-butyl $(=$ +21.38 ). As Laidler ${ }^{12}$ pointed out, extensive binding to an enzyme surface displaces water molecules formerly bound to that surface and consequent entropy increase can exceed the entropy loss associated with the formation of the enzyme inhibitor complex. The above data can be explained assuming that many water molecules are displaced as the substituent size or more fairly its hydrophobicity increases. The same relation was obtained with $p$-alkylphenyl methylcarbamates with slightly higher $\Delta S^{*}$ as compared with their meta analogues. Higher $\Delta S^{*}$ values of the para alkyl compounds over that of their meta analogues may be due to less complementariness of the para substituted compounds to the enzyme surface, and then less restriction of the activated complex of these compounds with the enzyme AChE. Interestingly, the contribution of the alkyl groups to the entropy of activation depends on the number of carbon atoms of the substituent. This contribution seems to be additive since a high and signifi- cant correlation $(\boldsymbol{r}=+0.99)$ was obtained between $\Delta S^{*}$ and the calculated molar refraction of the substituents.

In order to test whether the ejection of water molecules from the hydrophobic patch around the enzyme active site might be responsible for the contribution of substituent in the change in entropy of activation, $\Delta S^{*}$ values were related to the substituent hydrophobicity, $\pi$ substituent constant. ${ }^{13)}$ This relation shows a better approximation to a straight-line relationship, with a correlation coefficient of +0.99 .

\section{CONCLUSION}

In summary, the anticholinesterase activity of meta alkylphenyl methylcarbamates is greater than that of the unsubstituted parent compound and the activity increases as the substituent increases in size. In contrast, the para analogues are far less potent. Lower energy barrier, in addition to less decrease or increase in the standard entropy of activation, explains the higher potency of meta analogues. However, the higher energy barrier seems to be responsible for the reduced activity of the para analogues. Linear relations between the change in the standard entropy of activation and either the hydrophobicity or the molar refraction of the substituents were obtained with high and significant correlation coefficients.

\section{REFERENCES}

1) I. B. Wilson, M. A. Harrison \& S. Ginsburg: J. Biol. Chem. 236, 1498 (1961)

2) R. D. O'Brien, B. D. Hilton \& L. Gilmour: Mol. Pharmacol. 2, 593 (1966)

3) F. L. Hastings, A. R. Main \& F. Iverson: $J$. Agric. Food Chem. 18, 497 (1970)

4) R. L. Metcalf: Bull. W. H. O. 44, 43 (1971)

5) A. R. Main: Science 144, 992 (1964)

6) A. R. Main \& F. Iverson: Biochem. J. 100, 525 (1966)

7) A. R. Main \& F. L. Hastings: Science 154, 400 (1966)

8) Y. A. I. Abdel-Aal: Biochem. Pharmacol. 26, 2187 (1977)

9) Y. A. I. Abdel-Aal: IX International Congress of Plant Protection, Washington, D. C., USA, August 9-11, 1979

10) M. J. Kolbezen, R. L. Metcalf \& T. R. Fukuto: J. Agric. Food Chem. 2, 864 (1954) 
11) G. L. Ellman, K. D. Courtney, V. Andres, Jr. \& R. M. Featherstone: Biochem. Pharmacol. 7, 88 (1961)

12) K. J. Laidler: Discuss. Faraday Soc. 20, 83 (1955)

13) C. Hansch: "Biochemical Toxicology of Insecticides," ed. by R. D. O'Brien \& I. Yamamoto, p. 33, Academic Press, New York, 1970
要 約

アルキルフェニルメチルカーバメートによるア セチルコリンエステラーゼ阻害のエネルギー論 的解析

Yehia A. I. Abdel-Aal

メタアルキル置換フェニルメチルカーバメートの抗コ リンエステラーゼ活性は，無置換親化合物のそれよりも 大きく，置換基の大きさが増加するに従って活性も増加 する，これに反して，パラ置換体はその活性が低い，活 性化標準エントロピーのより少ない増減に加えるに，エ ネルギー障壁がより低いためにメタ置換体の活性が高く なると説明される。しかしながら，パラ置換体にあって はエネルギー障壁がより高いため活性が低くなると考え られる. 活性化標準エントロピーの変化と置換基の疎水 性または分子屈折との間には高度の有意な相関係数をも って直線的関係が得られている. 